\title{
The perspective transformation in illusionistic ceiling painting of late Baroque
}

\author{
Witold Szymański \\ https://orcid.org/0000-0002-5897-0822 \\ witold.szymanski@pwr.edu.pl
}

Department of Architecture and Visual Arts, Faculty of Architecture, Wroctaw University of Science and Technology

\section{Maurycy Kin}

https://orcid.org/0000-0001-5107-9327

mauycy.kin@pwr.edu.pl

Department of Acoustics and Multimedia, Faculty of Electronics,

Wroctaw University of Science and Technology

\begin{abstract}
Summary: The following work has shown the analyses carried out in order to clarify facts necessary to understand the phenomenon of the perspective representation in the works of art in Renaissanse and late Baroque. A lot of misunderstandings have arisen on the grounds of critical work made by many theoreticians and art historians. The aim of this work was to stipulate the reasons for the conceptual and methodological fallacies.

Having evaluated the methods used by illusionistic ceiling painters of late Baroque, it was possible to conduct some geometric analyses of the paintings placed on the vault of the Leopoldine Hall at the University of Wrocław.
\end{abstract}

Keywords: ceiling painting, illusion, non-reflective, anamorphosis

\section{Introduction}

The masterpieces of illusionistic ceiling painting prove that geometrically unclear perspective schemes drawn and described by Andrea Pozzo (Prospettiva di pittori e architetti Roma 1693) as well as works written by his followers, had practical applications.

Pozzo proved that physical phenomena (e.g. central projection) can be intuited. This form of perception has dominated every epoch but for the scientifically-oriented Hellenistic Period of ancient Greece. Although it was possible to make ingenious discoveries in the Renaissance and Baroque, they proved to be incomprehensible for further analyses. The use of perspective turned out to be the most problematic [1, 2]. As Paul Dirac puts it 'some scientists solve their equations and nothing comes out of it; the others however, and there are a few of them, know the results before they start counting' [3].

It can be noticed that different interpretations and understanding of central projection led to numerous divisions and conflicts. Defining perspective and its methods based on assumptions known from geometry, optics, psychophysiology and theory of vision was problematic. The central projection as a tool for perspective constitutes a physical law - every lit point emits the central beam in a form of a spherical ray which travels in all directions. The beam of light from the real space, converged in its focus, reaches the eye. In fact, the projected geometry or the human vision work the same.

For the observer placed in the center of projection, the projected image of objects either from geometric plane or the real space, remains the same. It also does not depend on a type of the perspective background which means that it can be the retina of a human eye. In order to see in the same way various images of the 
same objects but projected onto different surfaces (e.g. ceiling) only one condition has to be met. The viewpoint must coincide with the point from which the projection was made (explained in fig. 5). The practical perspective users, the ones who created ceiling paintings and used a beam of light as their tool for projection, knew it. Thanks to that it was possible to create distorted images of scenes and spatial representations, true anamorphoses. However, the history of perspective has shown, that even today it remains unclear for both the historians and reviewers.

\section{The perspective in Renaissance and Baroque}

In the Middle Ages the perspective representation on a plane was simply called a perspective. In Renaissance, the term perspectiva artificialis covered a great deal of forms developed and used by painters. It referred not only to perspective geometry, but also to a linear, converging, central, planimetric or collinear one. It was based on works by Leone Battista Alberti De pictura (On Painting, 1435) and PierodellaFrancesca De prospectiva pilgendi (also called aplicicata, practica) [3].

Firstly used to create perspective representation of the physical space in a painting, the perspective was later applied onto different surfaces. It led to creating numerous necessary methods of observation and schemes for construction. Albrecht Dürer and Leonardo da Vinci were the main representatives of the trend known as the constructivism. They both used wooden frames (Dürer's furta) with rectangular grids for the reference, glass drawings or mirror reflections (identical to the perspective image of a plane).These methods were exemplified in Dürer's woodblock prints and treatise: Instruction on Measurement, with Compass and Ruler, in Lines, Planes and Whole Bodies, 1525 [4]. The ancient Greeks noticed correspondence between the perspective of a human eye and the one achieved through direct observation or application of geometrical elements in their schemes or constructions. However, it is probable that they did not know that the eye creates focused two-dimensional image of the world on the spherical in shape retina. It seems they were aware that the optic images of straight lines become arcs since the source literature mentions Euclid's experiment where the cone of human vision is cut with a sphere [3].

Anamorphosis is one of the types of the central projection that should not go unnoticed. This subcategory of the modern perspective has been known for more than 500 years. However, it was barely used in Renaissance due to its complex projections and the general lack of interest in a visual illusion with the use of perspective distortion. A few experiments with the use of non-reflective anamorphoses were conducted by Leonardo da Vinci. In 1533 Hans Holbein rendered in The Ambassador an anamorphic perspective of the human skull. Earlier, in 1434 Jan van Eyeck (The Arnolfini Portrait), a painter interested in spherical reflections, unconsciously became a pioneer of their use in perspective representation. These spherical reflections, applied in the reflective anamorphoses became commonly used in Baroque, both in Europe and China.

The art historians have speculated a lot about the non-collinear perspective and its connections with the perspective of the human eye and psychophysiology, however their findings have always been controversial [3].

The Greeks applied the Congruence Rule according to their own methodology. For this reason abstract entities - forms created in speculum mentis would undergo experimental verification (speculum mundi), whereas physical phenomena needed theoretical frameworks.

These frameworks, created for reflections in several different types of mirrors (a plane, spherical, parabolic, cylindrical or cone mirror), as well as the follow-up research conducted by Alhazen, laid foundations for further development of the reflective an amorphoses and their optical systems in a form of cylindrical, cone and angular mirrors inBaroque.

The non-reflective ceiling anamorphoses, more commonly known as quadraturas, as an important trend of the illusory perspective were developed by Andrea Pozzo and his followers in $17^{\text {th }}$ and $18^{\text {th }}$ century. However, unlike their predecessors, they worked in different geometric conditions and used different projecting methods. As a perspective background they did not choose a flat canvas or a wall, but various shape vaults or domes [5]. The scale changed too. The ceiling paintings, often mistaken for frescos, were almost as big as the whole interior or its vault. The form and the size of these sublime masterpieces were to have emotional effects on their admirers [6]. 


\section{The Leopoldine Hall - illusionistic ceiling painting in geometric analyses}

The Leopoldine Hall is the most representative hall in the main building of what is today known as the University of Wrocław. The very name brings back the memory of the founder, Emperor Leopold I who, in 1639, temporarily donated the family castle to the Society of Jesus. The campus was constructed at the turn of $17^{\text {th }}$ and $18^{\text {th }}$ century and included the church (completed in 1700) and an academic institution later known as the University. In both cases, among the studied disciplines (mathesis), apart from geometry and astronomy there was architecture.
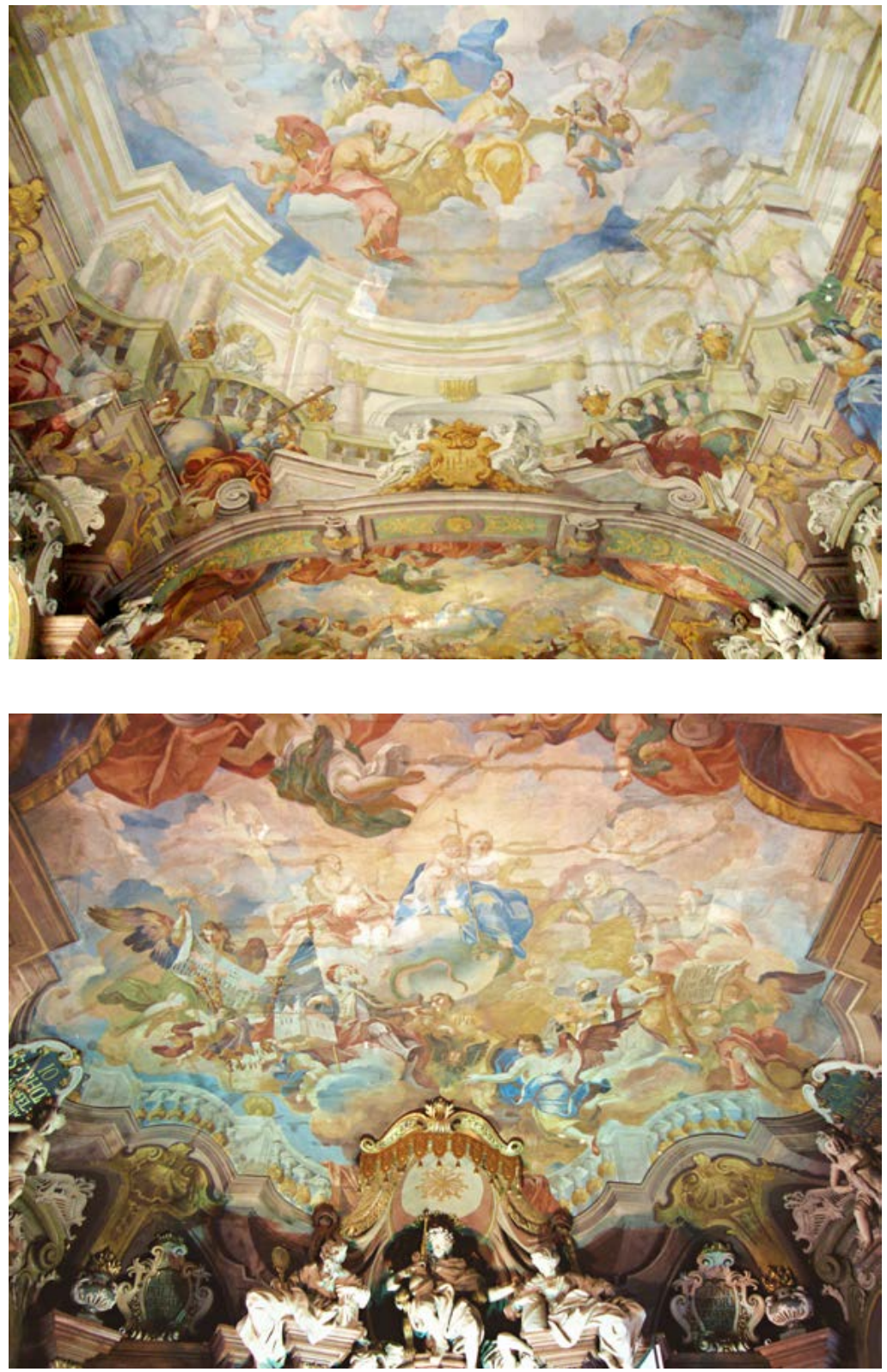

Fig. 1. The Leopoldine Hall in Wrocław - illusionistic ceiling painting. The author's private photo

Fig. 2. The Leopoldine Hall in Wrocław - illusionistic ceiling painting. The author's private photo 


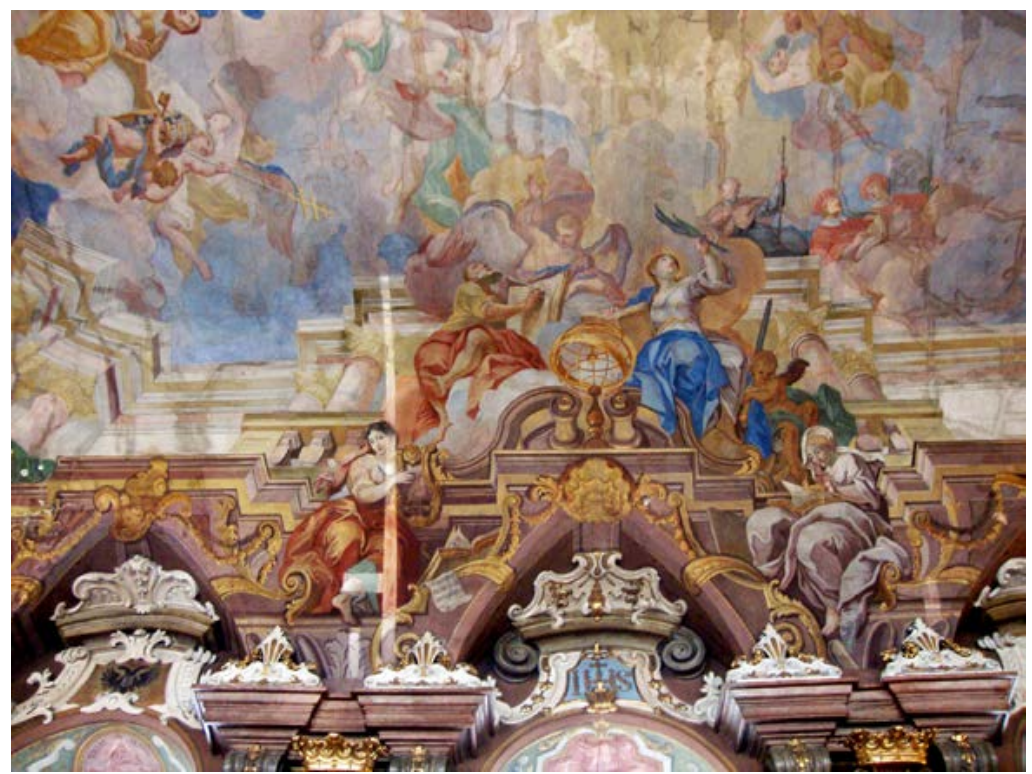

Fig. 3. The Leopoldine Hall in Wrocław - illusionistic ceiling painting. The author's private photo

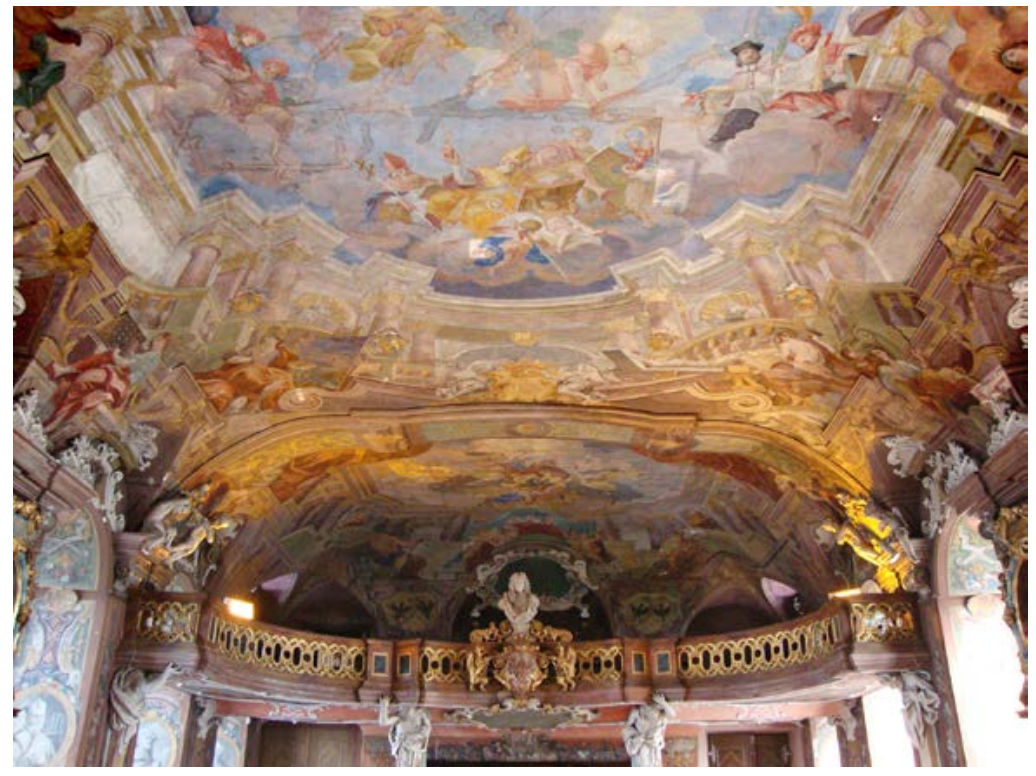

Fig. 4. The Leopoldine Hall in Wrocław - illusionistic ceiling painting. The author's private photo

Omitting many interesting facts relating to history and art, let us focus on geometry of projected images in their painted forms.

It has to be emphasized that despite the adverse spatial conditions of the Leopoldine Hall, the illusion is quite satisfying. For this reason such kind of the ceiling painting was so commonly used in Baroque.

Among the adverse conditions are:

the low interior in connection with the long spacious room - if the aim of the painter was to achieve three dimensional illusion of historical scenes admired from one point, it was not only uncomfortable, but also barely possible. To make the viewer's perspective more dynamic, it was necessary to introduce three vantage points : in front, in the middle and in the back of the room. Hence, the observed ceiling paintings have to be admired on the move. The paintings, set in motion by the movements of the visitors, become distorted. However, the distortion was not the case here, on the contrary, the distorted form of the ceiling anamorphosis was to make an impression of the non-distorted view. It was not fully possible in the Leopoldine Hall. 
almost flat slab (the centre plane of a part of the vault is joined with the edges of two cylindical planes). As a result one can see flattened barrel vault with a pseudoelliptic curvature. The height and length of the interior had their negative influence too. The painter could not do muchabout existing conditions. Let us imagine the ceiling in a form of an elliptic cylinder (with large axis variation). With this assumption we can define the curvatures of projected images in their linear or nonlinear forms. The latter, if they were conic sections, they were commonly used in Baroque. Images created with the central projection over quadric surfaces (so called quadrics) had various shapes. At this time the ceilings were created in spherical or ellipsoidal forms or, as in the Leopoldine Hall, they formed a barrel vault. That is why images created with the central projection over quadric surfaces (so called quadrics) had various shapes. Theyformed:

1. conical arcs, flat curves of the second degree creating illusion of cuboidal or linear architecturalforms;

2. arcs of space curves of the fourth degree creating illusion of circles, ellipses of arcs of these curves. All of these were used to depict architectural objects, figures of the saints, or symbolic forms (coats of arms, national emblems, or objects of worship). It needs to be emphasized that in painting, both geometric form and scheme have always played vital role e.g. in analyses of the human body or in its design [7].

\section{Discussion}

Distinguishing spatial concepts is one of many cognitive abilities of man who not only is able to create harmonies that have never existed before, but can also perceive them. Perception remains a human activity[8].

Existing source literature proves that there is a lock of conceptual and methodological consistency in relation to perspective and it has had a significant impact on visual arts. To clarify, the artists as the authors of the teatises had very limited theoretical background in the fields of scientific cognition and geometry. The scientific theory of perspective, namely projective geometry, was formed later, in the second half of the $19^{\text {th }}$ century by a Swiss mathematician Jacob Steiner [9].

Earlier, in Renaissance or Baroque, the artists applied geometric forms in their works but without creating much theory or methodology on the use of perspective. However, art historians have overestimated the importance of not fully authoritative theoretical works of

Leone Battista Alberti, Andrea Pozzo and many others of their times $[1,10]$. Their theories provided schemes and formulas applicable in flat, wall or ceiling painting but they lacked conceptual and research apparatus. All in all they had more practical than scientific use. Not based on assertions and without any proves, these theories did not provide adequate general overview. The reason for it lies in their limited knowledge of both scientific methodology and Euclidean geometry which provided foundation for modern science.

Over the time, conceptual inconsistency in relations to perspective has led to countless confusions. Various artist/theoreticians have fallen for the formal and logical fallacies. They could not differentiate real space conditions from the projection methods or properties of the real objects from the properties of their projected images. Confusing cause with effect alongside unprofessional overview was more typical for the authors of serious studies than the painters - authors of the treatises on perspective. The reviewers, interpreting the theories on the use of perspective, argued with one another over their interpretation and left behind value-laden comments. The authors of many acclaimed studies on art admitted clearly that they do not know much about the perspective [2]. Literature proves it so often that one could make a dictionary of the fallacies related to perspective $[2,9]$.

In the field of history of art studies on perspective have been compiling and in consequence inconsistent. The work of K. Bartel The Depiction of Distance seems to be the only exception [9]. However, the author omits the anamorphosis - a very important trend in the 500-year-old history of perspective representation development [11] . This technique needed most the support of advanced geometric tools.

A straight line determines a direction but in the real space the number of directions is unlimited. Therefore there is an infinite number of parallel lines which, in projected representation, become concurrent. The projected representation of the direction is determined by one point of concurrency, so the projected images of 
all of the directions in space fill in the perspective background. The source literature shows that there are 1-, 2- and 3-point perspectives, which remains one of the commonly reoccurring fallacies [2,9].

For some odd reasons there is no written evaluation of e.g. 17 or 24 -point perspective. Why? Known as the perspective, the represented image of the real life objects, consists of the projected images of the edge lines (if there are any). However, a sphere or some other forms with unlimited edges do not indicate the direction. So the projected image of a sphere does not have a projected point of concurrency.

It there were any 1-, 2-, 3- point perspectives, there would be the one that is $n$-point. This would lead to nonsense. It is claimed that the number of points of concurrency in the particular perspective is definite. Yet, because it is not determined by the projection method, the number of points of concurrency remains arbitrary.

One can ask about the projecting methods used by the artists. Their choice was a flat background, collineation or, like in the case of Baroque painters, the background (vault) of any geometric form leading to noncollinear perspective of projected images.

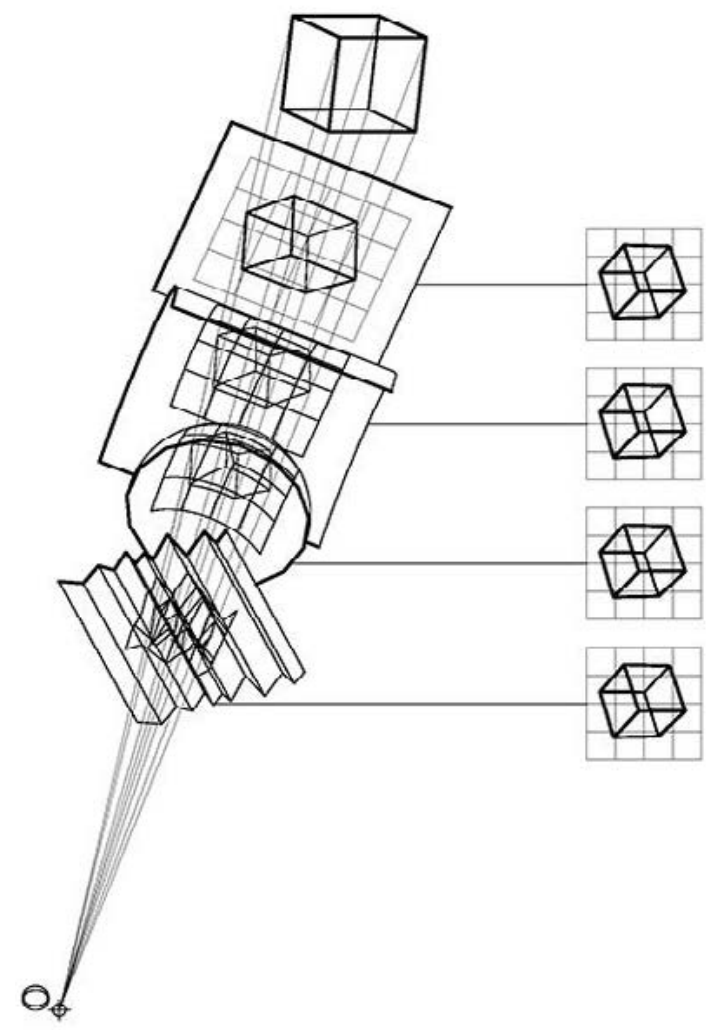

Fig. 5. Exemplary projection of a rectangular coordinate system onto different planes and its view from both the projection point and from any other vantage point. Drawn by the author.

The aforementioned conceptual and logical fallacies based on wrong methodology led to see the cause as the effect. For this reason it needs to be claimed that there are no different types of perspective representation, but only different formal representations of the projected images. Therefore, because the central projection has always been a major tool for creating projected images, it can be used on every type of surface; even, as in case of the classic painting, on flat planes.

Another false claim assumes the collinear perspective only approximately represents the perspective of the human eye. One of the conflicts relates to the spherical perspective whose origins E. Panofsky derives from ancient Greece [3]. The experiments with the use of this perspective, carried out in modern times, were criticized by the ones who favor the classical perspective. The findings, with a few exceptions, were not accepted by prominent representatives of painting, so the visual arts did not include them either. Even the artists themselves - the great illusionistic ceiling painters of late Baroque or their followers - outran their inadequate theories on central projection. 
It is easy to prove that the attempts to unify the non collinear perspective of the human eye with the flat geometric projection failed. The source literature shows several attempts to create hybrids of spherical and flat projection. There are examples where the object from a surface of a sphere becomes projected onto the cylindrical plane and later spread out on a flat plane $[2,5,11]$. Figure 5 presents the example of Cartesian coordinate system with the contained image of a cuboid projected onto different planes with the view given from the point of projection or any other vantage point.

If a perspective background is given in a form of a vault, e.g. paraboloidal, spherical or a barrel one, or in any complex geometric form, then the artists have to determine the best vantage point (sometimes more than one) to provide ultimate effects of illusion - three-dimentional images and space. It is enough to prove the correct understanding of the central projection represented on differently shaped planes. The anamorphoses or in another words quadraturas are these distorted images on the surfaces of the vaults which have no distortion if they are admired from the center of their projection [11]. The painters known from creating quadraturas are sometimes labeled quadraturists. Unfortunately, the term does not explain the essence of perspective representation, but the technique of projecting images with the use of light. It makes the whole process of making anamorphoses trivial and equal to a square grid, its secondary tool. Besides, 'quadratura' as a term refers to other fields of science too. The informal use of it proves little understanding of geometric complexity that true perspective involves $[10,12]$.The images of a square grid made of tight strings were common. They were projected onto a ceiling with the help of a spotlight or a candlelight [10]. It is shown in fig. 6.

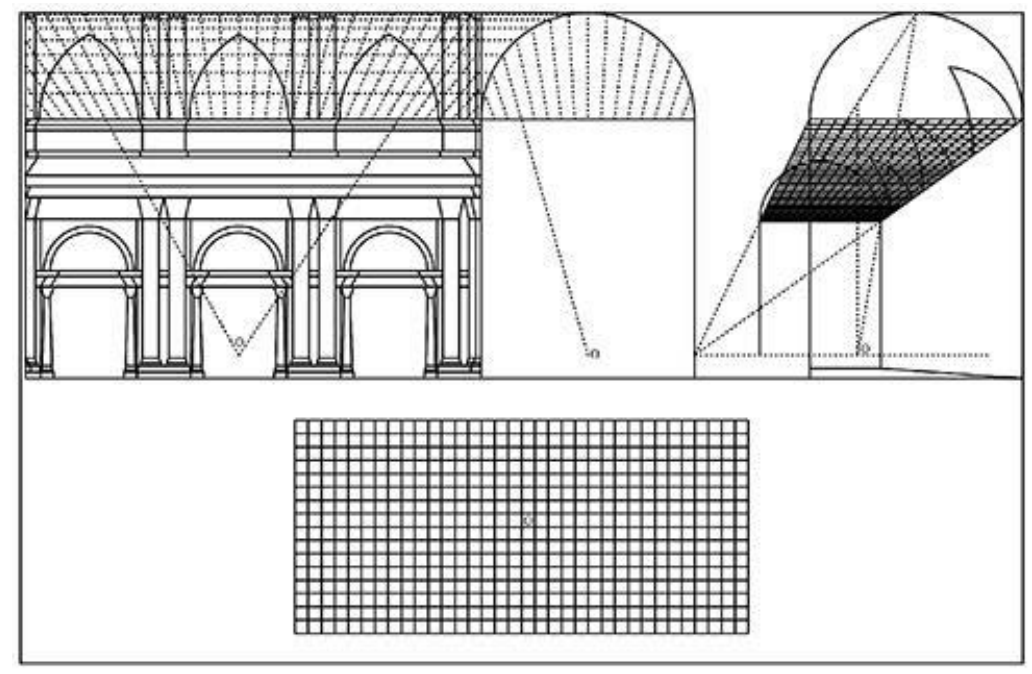

Fig. 6. Projecting tight-string square grid onto the ceiling with the use of a spotlight. The author's drawing based on a reproduction placed in [10].

Geometrically, it is a subtle perspective representation of one surface onto any other plane. As a result, one can achieve images of square shades projected onto a vault. First, a small scale design is made on a thin basecoat. Then, on top of it, the artist applies the square grid. Each square from the grid had its projected, distorted representation on the ceiling. That is why the projected image was distorted too. It proves that the artists knew the basic geometric properties of the central projection as a physical phenomenon. They owed this knowledge to the ancient Greeks and their Euclidean geometry [13].

Renaissance followers of Greek rational thinking were: Albrecht Dürer and Leonardo da Vinci. They were the authors of many popular schemes and instructions. Some of them referred to such complex techniques of perspective representation as anamorphoses. It is later, in the next period, that Pozzo becomes known as a great painter who uses central projection in his ceiling paintings [10,12]. However, except for its practical use, his theoretical work Perspectiva pictorum et architectorum has no scientific value.

Kazimierz Bartel appreciates the artistic value of Pozzo's drawings, but criticizes his use of geometry. Bartel points out that Pozzzo's work is compiled and the lines of his ellipses are far from the proper shape [9].

Several of the art historians have given credit to Pozzo's artistic achievements. Among them there is Jerzy Kowalczyk, an art historian whose evaluation of Pozzo's work is rather arbitrary. Kowalczyk, without enough evidence, considers Pozzo's theoretical work as a sort of course book for geometry. Moreover, he treats Pozzo 
like a discoverer of the perspective and reveller of its secrecy [12]. Let it be reminded here once again that the scientific theory of the central projection as a tool for perspective representation was created alongside projective geometry in $19^{\text {th }}$ century. Pozzo and other painters of his times learnt several practical tricks that enabled them to create projected representations of images on different planes which had useful applications in painting, however, their methods had nothing to do with geometry. All they needed was imagination and craft to achieve, with the use of light, breathtaking masterpieces of illusionistic ceiling paintings. Although commonly known, this fact seems to be forgotten.

\section{The Leopoldine Hall as an important concert hall in Wrocław}

Apart from obvious visual values, the Leopoldine Hall has the acoustic qualities which correspond with the spatial form of the room. Due to great acoustics, the Leopoldine Hall remains one of the major music halls in Wrocław. The barrel vault enables great sound reflection whereas the wooden elements reduce reverberation. All in all, the Hall imparts the feeling of closeness and creates nice atmosphere. Simply speaking, not only good sound is typical for this place, but also its stage area - large enough to make the performance well visible. The source literature has it that "... there are only two types of art known by men. The first one pertains to vision (painting, sculpture), whereas the second one relates to sound and speech (poetry, novel, drama, music). From all of the senses used by men, vision and hearing have always had the greatest impact on people's worldview..." [14]. Surprisingly, traffic noise pollution serves as a background correlating with the stage performance. So, both forms get their share in the final reviews [15]. Fortunately, the audience, thanks to great perception, can separate music from the noise, allowing the beauty of the Leopoldine Hall prevail. Ornate ceiling paintings corresponding with stage performances take the audience to a different realm where, during concerts, the high quality illusion mingles with breathtaking audio-visual effects [16].

\section{Conclussion}

The Leopoldine Hall served as an example needed to carry out geometric analyses of illusory vault paintings representive of the methods used by the artists of the late Baroque. These paintings, known as quadraturas, are in fact examples of distorted perspective known as the anamorphosis - one of the subtypes of the perspective representation with over 500-year-old history.

Having analysed the chosen fragments of the vault it turned out that many acknowledged theories on geometry and perspective proved to be wrong. Their wrong interpretations were based on conceptual and methodological fallacies. Knowing this, it was possible to stipulate the reason for the inconsistency and ambiguity in many works written by art historians or conceptual historians. Moreover, it was possible to remind some of the basic principles of projected representation and its methods. The character of distortion is determined by the conical arcs of the flat curves and the arcs of the fourth degree space curves. Above all this, this work provided a general overview of the acoustics in the Leopoldine Hall as one of the most prestigious concert halls in Wrocław.

\section{Bibliography}

[1] Rzepińska Maria, Leone Battista Alberti, O Malarstwie, Teksty źródłowe do dziejów teorii sztuki, PAN, Wrocław-Warszawa-Kraków 1963.

[2] Gonbrich Ernst H., Sztuka i złudzenie, Warszawa 1981.

[3] Feynman Richard P. Przyjemność poznawania, Warszawa 2006.

[4] Białostocki Jan, Albrecht Dürer jako pisarz i teoretyk, Wrocław 1956.

[5] Ludwig Bogna, Zastosowanie iluzji perspektywicznej w monumentalnych dekoracjach wnętrz śląskich świątyń w okresie późnego baroku, w: Architectus nr 2, str. 3, Wrocław 2004.

[6] Chwistek Leon, Przeżycia estetyczne, w: Wybór pism estetycznych, Universitas, Kraków 2004. 
[7] Dziurla Henryk, Mozrzymas Jan, Harmonia sfer w projekcie Leopoldiny, O nauce i sztuce, Studium Generale, Wrocław 2004.

[8] Konrad Lorenz, Regres człowieczeństwa, PIW Warszawa1986.

[9] Bartel Kazimierz, Perspektywa Malarska, tom I, II, Warszawa 1958, 1960.

[10] Kerber Bernhard, Andrea Pozzo, Walter de Gruyter - Berlin-New-York 1971.

[11] Baltrusaitis Jurgis, Anamorphoses les perspectives depravees, Flammarion, Paris 1984.

[12] Żaba Antonina, Czajor Jerzy, Traktat Andrea Pozzo „Perspectiva pictorum et architectorum" jako nowoczesny podręcznik dla barokowych kwadraturzystów, w: Biuletyn Polskiego Towarzystwa Geometrii i Grafiki Inżynierskiej Zeszyt 6 (1998/9).

[13] Russo Lucio, Zapomniana rewolucja - grecka myśl naukowa a nauka nowoczesna, Universitas, Kraków 2005.

[14] Bronowski Jacob, Źródła wiedzy i poznania, PIW, Warszawa 1984.

[15] Żurawski Juliusz, O budowie formy architektonicznej, w: Wybór pism estetycznych, Kraków, Universitas, 2008.

[16] Wallis Mieczysław, Sztuki i znaki, w: Wybór pism estetycznych, Universitas, Kraków 2004.

\section{Odwzorowanie perspektywiczne w iluzyjnym malarstwie nasklepiennym późnego baroku}

Streszczenie: W pracy przedstawiono analizę przyczyn wielu nieporozumień i sporów obecnych w komentarzach, opracowaniach, analizach i opisach historyków i teoretyków sztuki, dotyczących traktatów poświęconych zagadnieniom perspektywy w sztuce renesansu i baroku. Wskazano i zdefiniowano błędy pojęciowe i metodologiczne, jakich dopuszczają się oni w swoich opracowaniach, a także wyjaśniono ich przyczyny.

Przeanalizowano metody pracy artystów okresu późnego baroku specjalizujących się w nasklepiennym malarstwie iluzyjnym. Na tym tle przeprowadzono analizę geometryczną malowideł umieszczonych na sklepieniu Auli Leopoldina Uniwersytetu Wrocławskiego.

Słowa kluczowe: malowidła nasklepienne, iluzja, anamorfozy nierefleksyjne 